\title{
Empirical Analyis of Public ICT Development Project Objectives in Hungary
}

\author{
Márta Aranyossy \\ Department of Enterprise Finances \\ Corvinus University of Budapest \\ Budapest, Hungary
}

\author{
András Nemeslaki \\ Institute of E-Public Service \\ Development \\ National University of Public \\ Service \\ Budapest, Hungary
}

\author{
Adrienn Fekó \\ Prime Minister's Office \\ Public Administration Reform \\ Programmes Managing Authority \\ Budapest, Hungary
}

\begin{abstract}
E-government development in most European countries was ensured from Structural Funds in the period of 2007-2014. In our paper we show how Hungary has used these funds in order to achieve efficiency and effectiveness in its public services. The main objective of our research has been to explore the budgetary and timing characteristics of public ICT spending, and analyze the implicit and explicit objectives of eGovernment projects in Hungary. We applied exploratory text analyzes as a novel and objective way to analyze the focus of eGovernment development policy. Our main findings are:
\end{abstract}

- After the text analysis of 85 Electronic Public Administration Operational Programme (EPAOP) and 65 State Reform Operational Programme (SROP) projects we found that keyword statistics are generally consistent with the main policy level objectives of the Operative Programmes, however there are some fields which are not emphasized, such as: the role of participation, social partners, local-government; and the improvement need of user skills through public information campaigns.

- Governmental changes are clearly reflected in the goal hierarchy: contracting in EPAOP and SROP happened in two separate waves - the significant part of financing was committed during stabilized governments in the beginning and end phase of the planning period, with a relatively passive period during governmental change in 2010-2011.

\section{INTRODUCTION}

E-government, that is "the use of ICT and its application by the government for the provision of information and public services to the people" [1], is seen as a driver of government effectiveness and as a key source of competitiveness and economic growth worldwide and in the EU 28 member states [1], [2]. The EU therefore has been continuously pushing digital agenda policies and aligning financial support for eligible member states for e-government development. Effective use of these funds and closing the gap between advanced and lagging ICT adaptors is essential for EUs global competiveness and increased social cohesion.

When we look at actual data of eGovernment use (Fig.1) in the EU28 countries we find that only $41 \%$ of the EU28 population used e-services in 2013 which is down from $44 \%$ in 2012 and almost at the same level as it was in 2011. Currently only 9 out of 28 countries are above $50 \%$ eGovernment use, namely DK, NL, SE, FI, FR, LU, AT, SI, BE (although DE and $\mathrm{EE}$ are also close to it). In five countries (RO, IT, BG, PL and $\mathrm{HR}$ ) online public services are used by less than a quarter of the population with generally little progress in term of catching-up. The difference between the leading e-adaptor and the last ones (DK and RO) is more than $70 \%$ indicating a huge challenge in the EU's e-cohesion.

Keywords-eGovernment; eGovernment strategy; eGovernment policy; eGovernment goals

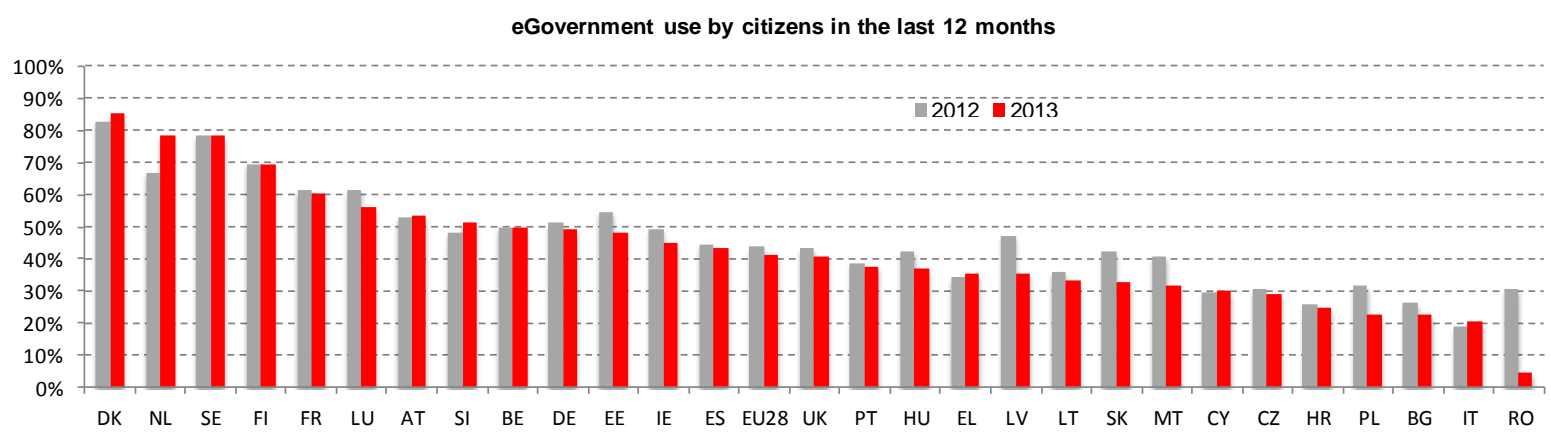

Fig. 1. eGovernemt use by citizens [3] 
When we look at user-centricity and transparency, the results for EU28 (Fig. 2) show that for many countries in the government domains the provision of user-friendly services is already a reality. Some countries still score 50 or less, displaying a rather analogue approach to public service delivery (SK, RO, HU, EL).

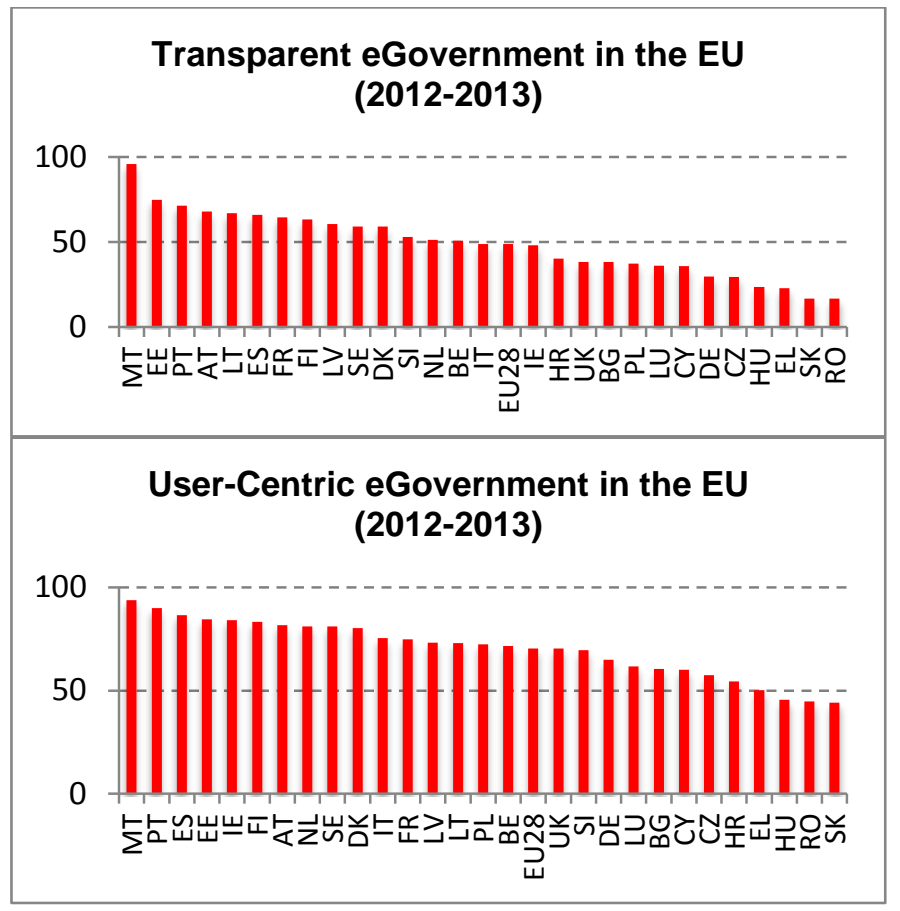

Fig. 2. User-centric and transparent eGovernment in the EU [3]

Transparency is an important element for increasing the take-up of online public services, since it helps building trust of citizens in public administrations. Data show that this important feature is still not positioned at the center of eGovernment strategies in case of many governments, except with few exceptions, and the variance between the leaders and the followers is reaching $80 \%$.

Improvement of e-cohesion - closing the digital gap between the leaders and laggers - is essential in the agenda of the European Commission's (EC) innovation strategy [7]. To provide financial resources for lagging countries, EC has created the European Structural Regional Funds (ESRF) and the European Social Cohesion Fund (ESF) which among their other targets transfer funds for ICT development to such European regions where GDP/capita is less than $75 \%$ of EU28 average. According to the Nomenclature of Territorial Units for Statistics (NUTS) these countries are called convergent regions and in the period 2014-2020 14 EU countries belong there.

Convergent region countries choose their own public ICT development strategies in alignment with the ESF and ESRF resulting in different paths to reach European e-cohesion. In our paper we show how Hungary - as a representative of these countries - has used these investments in order to achieve efficiency and effectiveness in its public services. As we see, Hungary is 16th in e-government usage, but 26th in user centric and 25th in transparent e-government services. How are these positions justified when in the period of 2007-2013 Hungary had spent $720 \mathrm{mEuros}$ from ESF and ESRF on ICT based modernization of government?

Hungary's case [4] is a relevant example of ICT investment effectiveness in the European public sector, especially when we compare how its eGovernment ranking has been changed over the 7 year period of the ESF and ESRF investment process (Fig. 3). Before the investment period Hungary's ranking position had been steadily improving it went up to 27 th word wide and 16th in the EU from 47 and 28 . Then during the 7 year period we can observe a decline until 2008, a short period of improvement until 2010 and since then a steady fall back again ending up in 39th and 25th in 2014, actually in a worse position than in 2007.

We carried out a detailed exploratory text analysis of project objectives, financial data, timing and duration of over 100 ESF and ESRF projects in order to identify

- basic project value and timing characteristics,

- key public IT development areas and

- major clusters of public ICT investments.

Our research expands to the period of 2007-2013 during which more than 720 million Euros where invested into ICT based modernization of Hungarian public administration. The lessons learned how this amount was deployed is essential to assess project results and impacts which will appear with a considerable time lag, but as an immediate importance, they are also indicative for the 2014-2020 planning period.

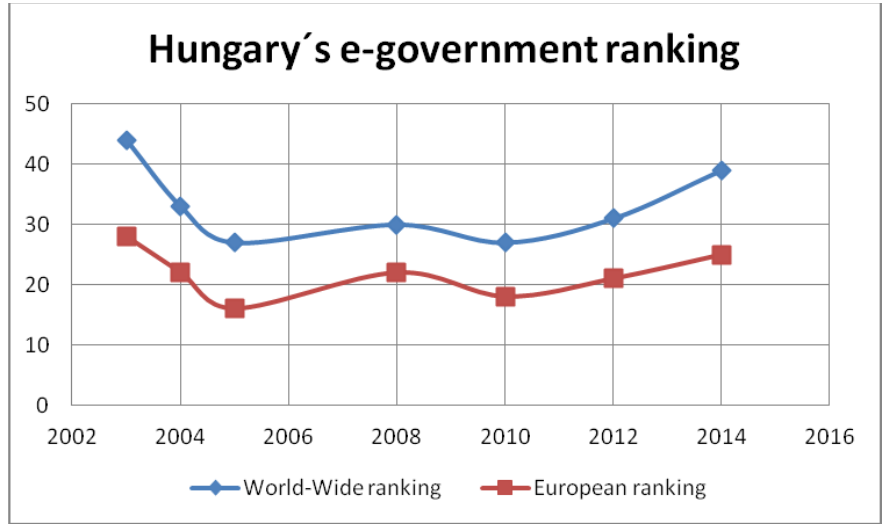

Fig. 3. Hungary's eGovernment ranking

Since ESF and ESRF ICT development resources will be very relevant in the following years, and since they impact many countries, we also intend to expand our research question into more general directions, that is, how the "independent" variable of the ICT investment equation is determined using the e-cohesion principles in the rather diverse EU28 environment.

After the introduction our paper is structured as follows. Firstly, we introduce the conceptual background of the two EU funds for public ICT development in Hungary, the main areas and budgetary and timing characteristics. Secondly, we describe the text mining research methodology and statistical tools we have used for analysing project objectives. In this 
section we also outline how the text analysis was combined with financial and project duration data in order to assess the value of particular development areas in public administration. In the third section we discuss our results, which will follow with conclusion and suggestions to expand both the scope and depth of research.

\section{CONCEPTUAL BACKGROUND OF PUBLIC ICT DEVELOPMENTS BASED ON STRUCTURAL AND COHESION FUNDS}

The value of ICT investment in the public sector can be assessed buy how much it helps to achieve better governance. Outcomes in this respect are connected to effectiveness and efficiency of public policy execution [5] such as healthcare, education, insurance, taxation and other areas of the modern state [6]. Since, the development of these policies is driven by political values the assessment of the final impact of good governance is determined by citizens votes in democratic societies. A major difference between e-business and egovernment, as some research has outlined, is that while in business the alignment and functional integrity of ICT management has been recognized and practiced, in public administration this has not been done yet as effectively as in business [5].

The ICT based value creation mechanisms usually grouped into two main groups for creating an infrastructure for effective public policy. The first group comprises visions related to integration. This group includes ideas such as desiloisation, inter-operability, the one-stop-shop, seamless government and portals. These are part of the wider picture of joined-upgovernment or whole-of-government. The second group relate to governance. In this group we find e-collaboration, econsultation, e-participation, e-voting and on-line voting which lead into more holistic concepts such as deliberative democracy and the creative commons [7].

Lips argues that e-government is still too techno-centric and many public officials associate e-Government with technology, with the technology deterministic attitude rather distant from the administrative complexity and political risk of governance [8]. Lack of strategic alignment then results in conceptual de-coupling of high-order objectives of governance and although several localized value and process improvement measures can be achieved breakthrough of transformation in government is still to come. As Frank Bannister and Regina Connolly [7] argues after looking into the past twenty years of e-government history that the concept of transformative government has not proved well defined and most of the time it used in conjunction with a large list of superfluous adjectives appealing to a great audience but missing a systematic breakdown and outline of interplay between technology and public administration [7].

Modernization of Hungarian public administration is based partly on the transformation of processes and procedures, and partly on the provision of extensive access to electronic public administration services to citizens. In order to streamline office work, it is necessary that the procedures are reorganized, technology is modernized, and these two areas systematically build on each other ([9] - as it is the case in the private sector, see also [10]). Service and technology modernization is provided by the Electronic Public Administration Operational Programme (EPAOP) while organizational and human resources modernization is ensured by the State Reform Operational Programme (SROP).

EPAOP is aimed to increase performance in public administration by means of ICT developments. The main objectives of EPAOP are: to reduce administration in the public sector, to improve the level of services and to assure effective operation of public administration. Electronic Public Administration Operational Programme has two main areas: convergence and regional competitiveness including employment. In order to achieve these, the programme is broken down to five priority axes listed in Table I.

TABLE I. ELECTRONIC PUblic AdMINISTRATION OpERATIONAL PROGRAMME (EPAOP) 1

\begin{tabular}{|lccr|}
\hline \multicolumn{1}{|c}{ Priority title } & Fund & $\begin{array}{c}\text { Budget } \\
\text { (million } \\
\text { EUR) }\end{array}$ & $\begin{array}{c}\text { Budget } \\
\text { (billion } \\
\text { HUF) }\end{array}$ \\
\hline $\begin{array}{l}\text { Priority 1: Public administration and } \\
\text { renewal of the internal processes of } \\
\text { administrative services }\end{array}$ & ERDF & 174.086 & 51.686 \\
$\begin{array}{l}\text { Priority 2: Projects promoting access to } \\
\text { public administration services }\end{array}$ & ERDF & 133.186 & 39.543 \\
$\begin{array}{l}\text { Priority 3: Priority projects } \\
\begin{array}{l}\text { Priority 4: Technical assistance in } \\
\text { convergence regions }\end{array}\end{array}$ & ERDF & 83.264 & 24.721 \\
$\begin{array}{l}\text { Priority 5: Technical assistance in the } \\
\text { Central Hungary region }\end{array}$ & ERDF & 5.632 & 1.672 \\
Source: [11] & & 1.526 & 0.453 \\
\hline
\end{tabular}

The mission of the State Reform Operational Programme (SROP) is to enhance the performance of the public administration system through institutional capacity building. The main objectives of SROP are: to improve human resources and to modernise the organisational operation. Accordingly, the priority axes of the operational programme are focusing on the two main resources of the public administration system, i.e. on the development of human resources and on organizational processes (see Table II).

Priority axes 1,2 and 3 are closely coupled on the OP level, since IT requirements for the projects of human and organisational objectives of SROPs are financed from EPAOPs. For the remainder of this paper we are going to focus on the Priority 1, 2 and 3 of both EPAOP and SROP. Table III. illustrates the total amount of contracted projects under EPAOP and SROP.

The framework amount of EPAOP is EUR 397.69 million, while the contracted amount is EUR 454.93 million. The main reason for this over commitment of the Hungarian Government is the fulfilment desire of the so called $n+2$ and $n+3$ goals $^{2}$ after the closure of the 2007-2013 programming cycle. On the contrary, in SROP the contracted sum reached only EUR

\footnotetext{
1 Applied exchange rate: 296,9 HUF/EUR. The 2013 annual average Hungarian National Bank HUF/EUR exchange rate - 296,9 - was used for conversion, but we do not intend to further analyze the currency or exchange rate related financial aspects of the OPs.

${ }^{2} \mathrm{~N}+3$ means that the allocation from Structural Funds must be used by the member states in 3 years or in case of $n+2$ in 2 years after the commitment.
} 
149,374 million, while the total framework would have allowed EUR 165,783 million. In this OP there were close to 10 projects which were under preparation or in the application phase during the time of our data collection.

TABLE II. STATE REForm Operational Programme (SROP)

\begin{tabular}{|llcc|}
\hline \multicolumn{1}{|c}{ Priority title } & Fund & $\begin{array}{c}\text { Budget } \\
\text { (million } \\
\text { EUR) }\end{array}$ & $\begin{array}{c}\text { Budget } \\
\text { (billion } \\
\text { HUF) }\end{array}$ \\
\hline $\begin{array}{l}\text { Priority 1: Renewal of processes and } \\
\text { organization development }\end{array}$ & ESF & 79.919 & 23.728 \\
$\begin{array}{l}\text { Priority 2: Improving the quality of human } \\
\text { resources }\end{array}$ & ESF & 31.819 & 9.447 \\
$\begin{array}{l}\text { Priority 3: Developments in the Central } \\
\text { Hungary Region }\end{array}$ & ESF & 47.420 & 14.079 \\
$\begin{array}{l}\text { Priority 4: Technical assistance in the } \\
\text { convergence regions }\end{array}$ & ESF & 4.651 & 1.381 \\
$\begin{array}{l}\text { Priority 5: Technical assistance in the } \\
\text { Central Hungary Region }\end{array}$ & ESF & 1.974 & 0.586 \\
\hline Source: [11 & & & \\
\hline
\end{tabular}

TABLE III. DESCRIPTIVE STATISTICS

\begin{tabular}{|c|c|c|c|c|}
\hline & $\begin{array}{l}\text { EPAOP } \\
\text { (million } \\
\text { EUR) } \\
\end{array}$ & $N$ & $\begin{array}{l}\text { SROP } \\
\text { (million } \\
\text { EUR) } \\
\end{array}$ & $N$ \\
\hline Contract sum - Total & 454.928 & 76 & 149.374 & 59 \\
\hline Priority 1 & 239.772 & 41 & 99.838 & 41 \\
\hline Priority 2 & 178.342 & 28 & 37.636 & 19 \\
\hline Priority 3 & 36.814 & 7 & 11.901 & 4 \\
\hline Contract sum - Average & 5.617 & 85 & 2.332 & 65 \\
\hline
\end{tabular}

Fig. 4 illustrates that contracting EPAOP and SROP happened in two separate waves with a relatively passive period in 2010-2011. Significant amount was committed relatively late in the planning period: in the second half of 2012 and during the year 2013, consequently these projects only close during 2014 or in 2015.

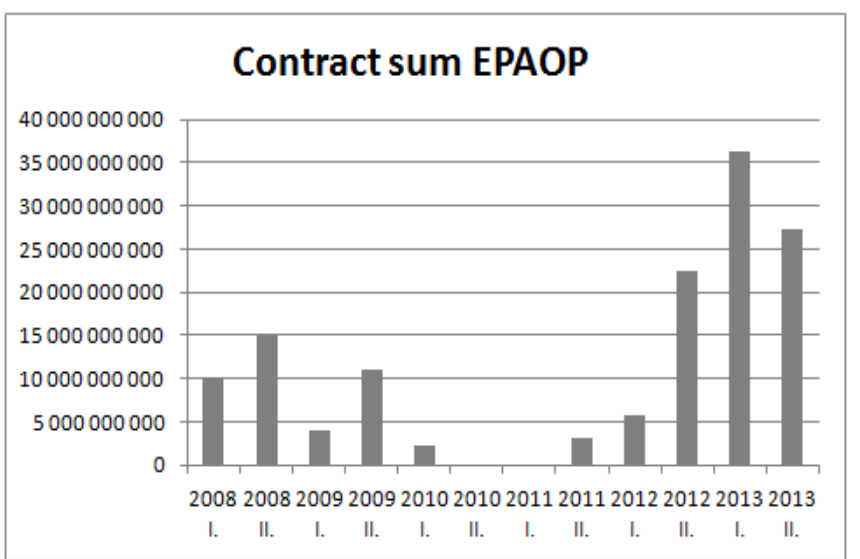

Fig. 4. Hungary's eGovernment ranking

\section{RESEARCH METHODOLOGY}

For the detailed analysis of EPAOP and SROP Priority 1, 2 and 3 objectives and project spending we used data available from the website of the Hungarian National Development Agency (palyazat.gov.hu ${ }^{3}, 2013$ ) and from the website of DG Region and DG Employment. We collected the following data and organized them in a standardized format: the contract sum of the projects, main aims of the projects, indicators used, planned project start, actual project start, planned project end, payment rate, and status of the projects. For the analysis of the text based objective statements and indicators in order to get a structured and objective insight about the documented goals of the projects we used text analysis techniques (word frequency analysis) and text analysis software (NVivo and Textrend Core 1.0). The methodology enabled us to identify the smallest components of the development objectives, compare them with the official policy's goal system, the priority axes and analyze them across governmental periods.

First we identified the most frequent 200 words (keywords) in the objective section of the feasibility studies in each of the project documentations, filtering out conjunctions and different forms of the same words. Then the authors decided (with a majority rule) on the top 100 keywords filtering out general meaning words, which could not be interpreted in the context of the eGovernment OPs. Two different lists of keywords were created, one for EPAOP, and one for SROP. We visualized some of our findings in the form of word frequency based wordclouds (where font size directly reflects the differences in keyword frequency). We used the frequency of these final set of keywords as variables in the further analysis. (Coding: $0-$ the keyword did not occur in the project objective; 1 - the keyword occurred one time in the project objective; 2- the keyword occurred more than once in the project objective.) We also created a weighted list of keyword frequencies, were the number of occurrence of the different keywords were weighted by the contract sum (in HUF million) of the projects. Multivariate statistical methods (cluster analysis) and statistical tests (comparing frequencies and means) were applied to get a more in-depth understanding of the implicit goal structure of the projects.

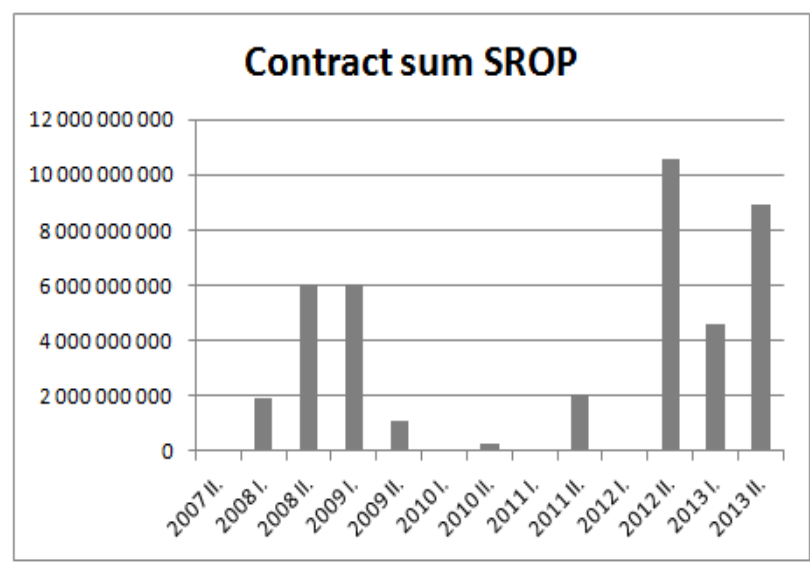

\footnotetext{
${ }^{3}$ The website of National Development Agency until 31 December 2013.
} 


\section{DISCUSSION AND FINDINGS}

In Table IV we summarize our key findings on keyword priorities of EPAOP and SROP objectives. Both the normal count and the weighted frequency are in alignment with the generally stated objectives of these program portfolios, and show coherence. It is interesting to notice, however, that the leading keyword in the contract sum weighted list of SROP is "data" preceding the more general terms describing "organization", "development" and "public administration". From Table IV we can also observe the interplay between the initiatives of ICT based and human capacity based developments (EPAOP vs. SROP keywords): the first listing "systems", "service" and "ICT support", while the second focusing on "data", "organizations", and "public administration support".

In order to adhere to the spatial limitation of the paper we present three findings from our analysis. Firstly we discuss how Priorities 1 and 2 in both EPAOP and SROP goal systems are structured. Secondly, we look at the relationship between the goal structure of EPAOP and SROP projects. Thirdly, we re-aggregate the decomposed objective elements according to the timeline of the 2007-2013 planning period and draw conclusion on the modernization priorities of the three governments in this era.
TABLE IV. TOP 20 KEYWORDS IN EPAOP AND SROP

\begin{tabular}{|lr|ll|}
\hline \multicolumn{1}{|c|}{ EPAOP } & \multicolumn{2}{c|}{ SROP } \\
\hline Keyword & Count & Keyword & Count \\
\hline system & 108 & project & 59 \\
\hline project & 92 & objective & 55 \\
\hline service & 90 & public & 46 \\
\hline data & 83 & necessary & 32 \\
\hline development & 78 & organizational & 25 \\
\hline electronic & 72 & public administration & 18 \\
\hline formation & 63 & tender & 18 \\
\hline client & 48 & integrate & 16 \\
\hline effective & 47 & development & 15 \\
\hline support & 47 & objective & 15 \\
\hline administration & 47 & system & 13 \\
\hline integrate & 45 & new & 13 \\
\hline public administration & 40 & municipality & 12 \\
\hline relation & 40 & societal & 12 \\
\hline application & 37 & program & 11 \\
\hline registration & 37 & design & 11 \\
\hline central & 33 & form & 11 \\
\hline opportunity & 32 & state & 11 \\
\hline modern & 30 & effective & 11 \\
\hline total & 30 & adequate & 11 \\
\hline & & & \\
\hline
\end{tabular}

TABLE V. EPAOP OFFICIAL PRIORITY GOALS VERSUS KEYWORDS

\begin{tabular}{|c|c|c|}
\hline Priority & $\begin{array}{l}\text { EPAOP Priority goals in the official } \\
\text { EPAOP document }\end{array}$ & $\begin{array}{l}\text { Keywords based on objective text analysis } \\
\text { (with priority-level frequency) }\end{array}$ \\
\hline \multirow[t]{4}{*}{$\begin{array}{l}\text { Priority } \\
1.1\end{array}$} & $\begin{array}{l}\text { Electronization of public administration services and } \\
\text { to raise the level of transactions }\end{array}$ & $\begin{array}{l}\text { Electronic (35); informatics (43); public administration (16); service (36); development } \\
\text { (46); integrated (26), central (11); project (48); data (52); hardware (8); software (13); } \\
\text { server (6) }\end{array}$ \\
\hline & $\begin{array}{l}\text { The renewal of the procedures and IT support of } \\
\text { judicial system and the registry court }\end{array}$ & $\begin{array}{l}\text { Renewal (5); procedure (19); execution (of penalty; 21; support (36); process (16); project } \\
\text { (48); punishment (system) }\end{array}$ \\
\hline & Setting-up service centres for local governments & $\begin{array}{l}\text { Service (36), project (48), public administration (16); integrated (26); processes (16); } \\
\text { relation (22) }\end{array}$ \\
\hline & $\begin{array}{l}\text { IT background of law enforcement, emergency } \\
\text { organisations and public persecution offices }\end{array}$ & $\begin{array}{l}\text { Project (48); magisterial (14); informatics (43); public administration (16); execution (of } \\
\text { penalty; 21); support (36); process (16); relation (22); development (46); hardware (8); } \\
\text { software (13) }\end{array}$ \\
\hline \multirow[t]{4}{*}{$\begin{array}{l}\text { Priority } \\
1.2\end{array}$} & $\begin{array}{l}\text { Establish the central electronic services required for } \\
\text { the efficient operation of public administration }\end{array}$ & $\begin{array}{l}\text { Central (11); electronic (35); service (36); effective (25); public administration (16); ); } \\
\text { hardware (8); software (13); server (6); project (48); infrastructure (12), integrated (26); } \\
\text { network (6), support (36), development (46); modern (18); organisation (12) }\end{array}$ \\
\hline & $\begin{array}{l}\text { Establishment of data links among public } \\
\text { administration systems }\end{array}$ & $\begin{array}{l}\text { Data (52); relation (22); public administration (16); project (48); functional (9); processes } \\
\text { (16) }\end{array}$ \\
\hline & $\begin{array}{l}\text { Implementation of electronic document } \\
\text { management system. }\end{array}$ & $\begin{array}{l}\text { Electronic (35); procedure (19); project (48); hardware (8); software (13); central (11); } \\
\text { complex (11); database (11); service (36) }\end{array}$ \\
\hline & $\begin{array}{l}\text { Modernisation of the financial and } \\
\text { economic operation processes. }\end{array}$ & Internal (11); processes (16); modern (18); service (36) \\
\hline \multirow[t]{4}{*}{$\begin{array}{l}\text { Priority } \\
2.1\end{array}$} & Provision of service interface for clients. & $\begin{array}{l}\text { Service (47), integrate (14), central (17), electronic (31), project (39), data (28), informatics } \\
\text { (13), application (16), client (26) }\end{array}$ \\
\hline & Central client interface services. & Central (17), client (26), service (47), development (24), electronic (31), integrate (14) \\
\hline & Electronic payment system. & Electronic (31), project (39), integrate (14), central (17), client (26) \\
\hline & $\begin{array}{l}\text { Front office services, common territorial service } \\
\text { centres, upgrade of government offices }\end{array}$ & $\begin{array}{l}\text { Service (47), public administration (20), state (5), development (24), governmental (7), } \\
\text { project (39), integrate (14) }\end{array}$ \\
\hline $\begin{array}{l}\text { Priority } \\
2.2\end{array}$ & $\begin{array}{l}\text { Development of the Central Electronic Service } \\
\text { System and IT security infrastructure. }\end{array}$ & $\begin{array}{l}\text { Development (24), central (17), electronic (31), service (47), safety (5), hardware (2); } \\
\text { software (2); server (1); citizens (7), public administration (20), project (39), data (28), } \\
\text { information (8), info-communicational (2) }\end{array}$ \\
\hline $\begin{array}{l}\text { Priority } \\
2.3\end{array}$ & Electronic authentication of citizens & $\begin{array}{l}\text { Certified (0), identification (3), citizens (7), processes (4), project (39), client (26), data } \\
(28) \text {, administration (23), centralised (1) }\end{array}$ \\
\hline
\end{tabular}




\section{A. EPAOP objectives - ICT supported reorganisation of internal processes in public administration and access to public administration services}

To illustrate the goal-consistencies between EPAOP and SROP projects through keyword connections we compared Priority axes 1 and 2 high level policy objectives and the most frequent keywords. In Table V. we summarised our results concerning the EPAOP projects.

In order to provide a visual demonstration of keyword frequencies and goal congruence we created the word cloud figures of EPAOP for the two main priority axes:

- Priority axis 1 - Public administration and renewal of the internal processes of administrative services (Fig. 5.), and

- Priority axis 2 - Financing projects and promoting access to public administration services (Fig. 6.).

The most frequent EPAOP Priority 1 keywords were: "data", "project", "development", "informatics", "service", support", "electronic", "formation". These words appeared in the analysed project goals 33-52 times. The less frequent words (which appear 1-4 times only) are usually related to the special project topics, such as "land register", "agricultural", "taxpayers". In addition to the keywords we can also look at the most important projects in terms of their allocated budgets. The most significant EPAOP Priority 1 financed projects (i.e. projects with a budget above HUF 2billion - EUR 6,7million) served the following objectives: "the modernisation of financial and economic operation processes", "the efficient support of the work processes of public administration organisations"; "the implementation of monitoring and decision support systems" and "the IT development of the organisations providing back-office functions for public administration". These fields are of key importance and have been highly emphasized among project goals.

As we can see in Table V, the keywords based on objective text analysis usually cover the sub priorities' goals, but there are some exceptions. In the documents of EPAOP the following objectives are also of key importance: "centres for local governments, the local public administration framework, ASP (Application Service Providers)" and the "implementation

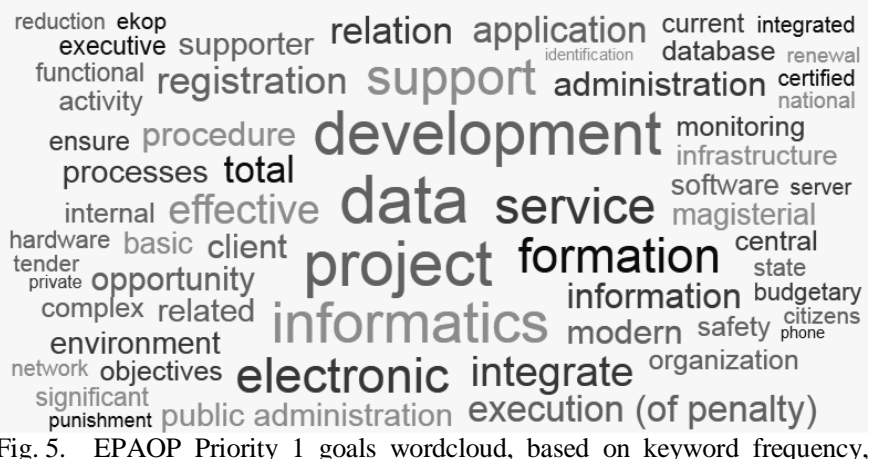

Fig. 5. EPAOP Priority 1 goals wordcloud, based on keyword frequency, where font sizes reflect word frequency

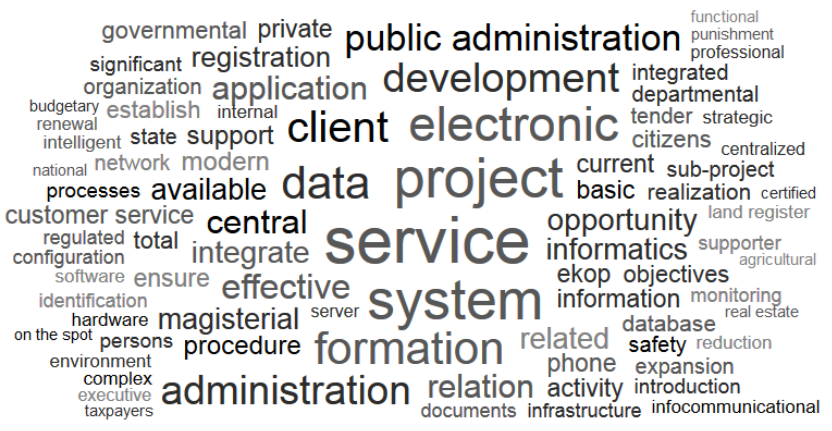

Fig. 6. EPAOP Priority 2 goals wordcloud, based on keyword frequency, where font sizes reflect word frequency

of electronic document management system". We have found during the word frequency analysis that these objectives cannot be prominently seen in the objective keyword frequency lists.

The reasons behind this might be, that ASPs and the electronic document management systems are financed from Priority 3 of EPAOP and will be realised only in the Central Hungary Region of Hungary.

As visualised on Fig. 6, the most frequent keywords under EPAOP Priority 2 are "service", "project", "system" and "electronic" (with frequency above 30). As Priority 2 aims to develop citizens' access to services, the role of "client" is of key importance - the keyword "client" occurred 26 times among project goals. The word "central" (17 occurrence) is also necessary to the fulfil Priority 2 goals, as the systems should be implemented centrally and they should also be "integrated" (14 occurrence). Among the dedicated objectives, the improvement of user skills remained only on the level of plans, regardless of the fact that it should have been one of the key objectives of the programme in order to increase the level of usage of public electronic services.

Neither appears electronic authentication of citizens accentuated at all in the word cloud, probably because the topic is covered by one main project ("Complex customer identification”, EUR 7.22 million), so the keyword frequency was not so high, but the term "identification" appears in Fig. 6.

\section{B. SROP objectives - human resources capability development}

As we described earlier the State Reform Operational Programme supports the establishment of the organisational structure of institutions followed by the human resources and procedural adoption of the new or improved organizational structures. The first 3 priority axis of SROP finance projects are closely related to eGovernment development in Hungary. In Table VI we compared the policy-level official goals of SROP Priority 1 and 2 with the findings of the objective statement's text analysis. Fig. 7 and 8 show the frequencybased wordclouds visualising SROP Priority 1 and 2 goal system.

SROP Priority 1 focuses on the renewal of processes and organisation development in public administration. Under SROP Priority 1 objectives "public administration" was mentioned at 26 times, "operation" 24 times, "law" 20 times. Other words occurred less than 20 times in the projects. 
"Development", "effective", “organisational" 19 times, "process, system, necessary" 16 times, and "support" 15 times. "Internal", "integrate", "governmental" and "services" proved also as important keywords in SROP projects - these were mentioned 13 times.

TABLE VI. SROP OFFICIAL PRIORITY GOALS VERSUS KEYWORDS FROM OBJECTIVE TEXT ANALYSIS

\begin{tabular}{|c|c|c|}
\hline Priority & Priority goals in the official SROP document & $\begin{array}{l}\text { Keywords based on objective text analysis } \\
\text { (with priority-level frequency) }\end{array}$ \\
\hline \multirow[t]{3}{*}{ Priority 1.1} & $\begin{array}{l}\text { Improvement of the capacity for governance and local } \\
\text { government }\end{array}$ & $\begin{array}{l}\text { Training (1), effective (19), performance (8), governmental (13), project (38), operation } \\
\text { (24), development (19) }\end{array}$ \\
\hline & Raising the quality of legislation & Law (20), project (38), organizational (19), simplifications (5), process (16) \\
\hline & Active involvement of the social partners & - \\
\hline \multirow[t]{3}{*}{ Priority 1.2} & $\begin{array}{l}\text { Renewal of procedures and work processes as well as } \\
\text { organisation development }\end{array}$ & $\begin{array}{l}\text { New (12), process (16), organisational (19), development (19), project (38), problems } \\
\text { (4), realisation (4) }\end{array}$ \\
\hline & $\begin{array}{l}\text { Transformation of the case handling } \\
\text { administration procedures }\end{array}$ & Transformation (3), process (16), simplification (5), organisations (6), project (38) \\
\hline & $\begin{array}{l}\text { Development of the efficient and cost- } \\
\text { effective organisations }\end{array}$ & $\begin{array}{l}\text { Development (19), effective (19), organisational (19), culture (4), governmental (13), } \\
\text { project (38) }\end{array}$ \\
\hline Priority 2.1 & $\begin{array}{l}\text { Establishment of open recruitment and an efficient } \\
\text { internal replacement }\end{array}$ & $\begin{array}{l}\text { Effective (7), internal (3), electronic (3), knowledge (4), public administration (28), } \\
\text { training (21), system (14), project (17) }\end{array}$ \\
\hline Priority 2.2 & Performance-based career pathways & Effective (7), training (21), career (4), project (17) \\
\hline
\end{tabular}

Regarding the most frequent keywords we can assume that the official SROP goals are generally well translated into planned project goals, since all of the keywords of Priority 1's general objectives occur more than 10 times (Fig. 7.): "new, processes, organisation and development". It is interesting to see, however, that one of the main Priority 1 goals, "involvement of social partners" cannot be seen in terms of frequent objective key words. The authors' assumption is that these objectives are left out due to other more important aims, and/or the related projects were under preparation or in the application phase during the data collection.

SROP Priority 2 aims to improve the quality of human resources in the public sector. Priority 2 official goals were usually covered by the project objectives, that is what the keyword frequency analysis shows. The most frequent keywords are (Fig. 8.): "public administration", "training", "project", "system", "necessary".

Summarising the results of our keyword frequency analysis of EPAOP and SROP projects we can state that the keyword frequencies and wordclouds generally do illustrate the main policy level objectives of the Operative Programmes, however, there are some fields which are not emphasized among project goals - such as:

- the role of participation and social partners, and local government;

- improvement of user skills through public information campaigns.

We also have to reflect on the geographical coverage of the projects. There are some project goals which did not meet the broader objective of regional convergence; these were only applicable in the Central Hungary region. This poses a major challenge for the programming period of 2014-2020 in order to assure a countrywide coverage of development projects and goals. For example the ASP project has been implemented in the Central Hungary Region, but it seems an important aim to assure ASP services countrywide especially for productivity improvement in local governments. Another important priority area sticks out from the analysis: the topic of electronic file and document management systems, that is to widen the usage of these solutions countrywide.

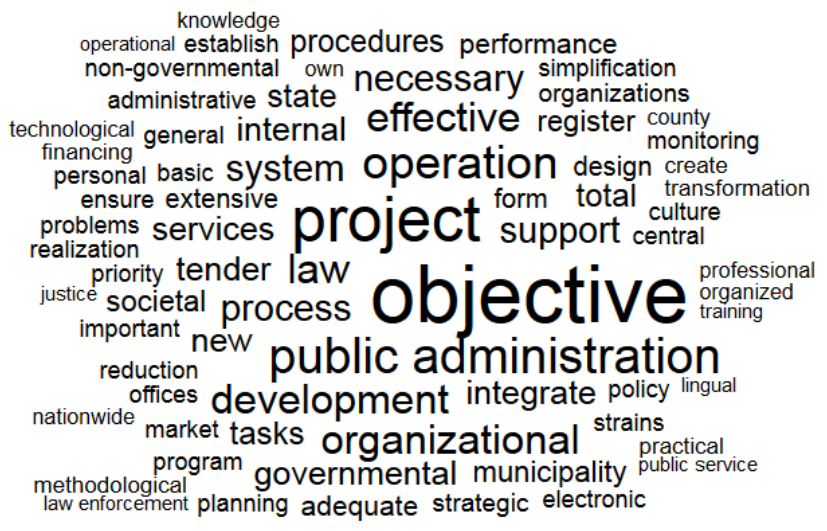

Fig. 7. SROP Priority 1 goals wordcloud, based on keyword frequency, where font sizes reflect word frequency

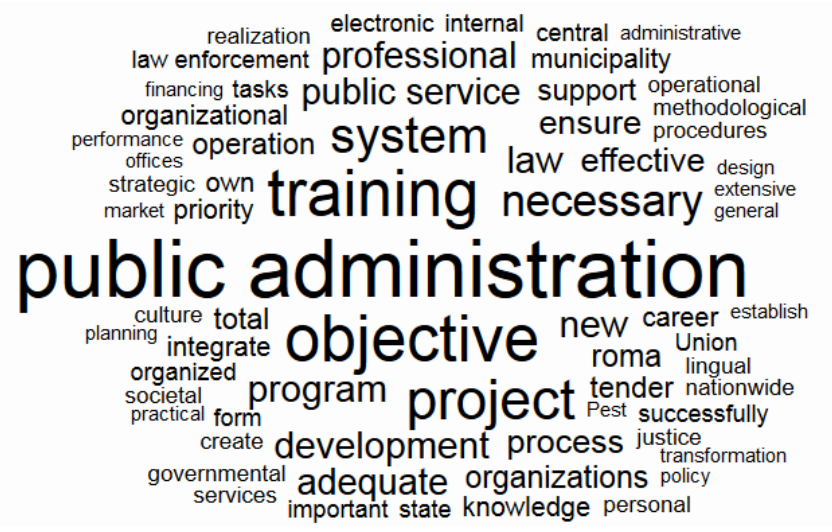

Fig. 8. SROP Priority 2 goals wordcloud, based on keyword frequency, where font sizes reflect word frequency 


\begin{tabular}{|c|c|c|}
\hline \multirow{2}{*}{$\begin{array}{c}\text { Cluster } 13 \\
(\mathrm{~N}=60,17 \text { EPAOP, } 43 \text { SROP) } \\
\text { project, service, development } \\
\text { Average contract sum: } 3,39 \mathrm{M} \text { EUR } \\
\text { Project start: } 09.10 .2011 \text {. } \\
\text { Planned project duration: } 20,4 \text { month } \\
\text { Payment rate: } 58 \%\end{array}$} & $\begin{array}{c}\text { Cluster 10 } \\
(\mathrm{N}=25 ; 14 \text { EPAOP, } 11 \text { SROP) } \\
\text { electronic public administration } \\
\text { effective central project system } \\
\text { service development formation } \\
\text { Average contract sum: } 4,53 \mathrm{M} \text { EUR } \\
\text { Project start: } 23.01,2012 \\
\text { Planned project duration: } 20 \text { month } \\
\text { Payment rate: } 29 \%\end{array}$ & $\begin{array}{c}\text { Cluster 11 } \\
\text { (N=12; 11 EPAOP,1 SROP) } \\
\text { data electronic information } \\
\text { integrate effective related modern } \\
\text { opportunity registration project } \\
\text { system service development } \\
\text { formation support } \\
\text { Average contract sum: } 4,98 \mathrm{M} \text { EUR } \\
\text { Project start: } 26.02 .2011 \\
\text { Planned project duration: } 31,6 \text { month } \\
\text { Payment rate: } 67 \%\end{array}$ \\
\hline & $\begin{array}{c}\text { Cluster } 3 \\
\text { (N=35; } 20 \text { EPAOP, 15 SROP) } \\
\text { data, project, system } \\
\text { Average contract sum: } 3,31 \mathrm{M} \text { EUR } \\
\text { Project start: } 30.07 .2011 \\
\text { Planned project duration: } 19,7 \text { month } \\
\text { Payment rate: } 52 \%\end{array}$ & \begin{tabular}{|c} 
Cluster 2 \\
(N=12; 12 EPAOP) \\
client data database electronic \\
magisterial public administration \\
effective opportunity application \\
relation registration project \\
system service development \\
formation procedure \\
administration \\
Average contract sum: $7,88 \mathrm{M}$ EUR \\
Project start: 26.09 .2010 \\
Planned project duration: 25,2 month \\
Payment rate: $58 \%$
\end{tabular} \\
\hline
\end{tabular}

Fig. 9. EPAOP-SROP mixed cluster analysis - displaying the most frequent keywords (average frequency > 0,5), and other descriptive characteristics

\section{Harmonization of eGovernmentgoals in ICT versus human capacity related projects}

After decomposing the goal structure of EPAOP and SROP projects, in order to identify the implicit goal hierarchy and compare it with the official policy targets, we used cluster analysis to reveal the emergent relationships of EPAOP and SROP projects based on similarities of their objective structure (described by the keyword frequencies). During the cluster analysis 14 clusters were identified, but only the ones with $\mathrm{N}>3$ were included in the further analysis, and these are shown inn Fig. 6. presenting the number of projects, average budget, duration, and key objectives.

We can see, that while some clusters include projects only either from EPAOP or SROP, there are some mixed-clusters as well (Cluster 13, 10 and Cluster 3 in Fig. 9). This suggests that some EPOP and SROP projects have similar implicit goal structure - supporting the original policy level intention of financing technology support of SROP organisational development from EPAOP projects. One of these metaclusters, Cluster 3 is characterized by general system development keywords only, while the mixed Cluster 13 is more focused on service development. From our analytical point of view the most interesting is Cluster 10, which includes projects from both operative programmes with prominent keywords like "electronic" "service" "development", and characteristics like "central" and "effective". By looking at their other attributes of this cluster we can say, that these projects had short planned durations, long delays, and by the time of our data collection most of them were uncompleted.

Fig. 9 also illustrates that the largest projects tend to belong to the two smaller and more specific EPAOP clusters (Cluster 11 and 2), showing that higher average budget values goes hand in hand with higher project durations and usually higher payment (and completion) rates as well.

\section{Different aspects of modernization in the planning period}

During our research design we assumed that governmental vision might influence the main objectives and other characteristics of eGovernment projects. Fig. 10. illustrates the differences of keyword frequency in the different governmental periods during 2007-2013.

In the period 2007-2008 „Gyurcsány Government” and 2009-2010 "Bajnai Government" the development and IT support of the judicial systems was important while these keywords got less dominant in the succeeding government periods. While "strategic" approach was frequent in the „Gyurcsány Government”, some of the prevalent keywords in the "Orbán Government" were "integrate", "opportunity", "formation" and "realization", suggesting a different - more execution oriented - approach to eGovernment development.

In the first and third governmental cycle the average contract sum of projects was quite high (EUR 5,25 and 4,21 million), corresponding with the project durations which was longer than 2 years on average, compared with the "Bajnai Government" period which financed significantly smaller projects (EUR 2,67million). It is interesting to note, that the „Gyurcsány Government" started long projects (30 month in average), while the next two governments launched significantly shorter projects (22 and 20 month).

If we take into account the main implications in Fig. 1. and we link it with the governmental periods, we can observe that after the "Bajnai Government" there was a relatively passive period in the implementation of EPAOP and SROP projects (between 2010 and 2012 second half year), the implementation continued only in the second half of year 2012, with a slight shift in focus in terms of objectives, and also in beneficiaries 
and project sizes. The biggest proportion of projects was launched in the period of the „Orbán Government”, both in

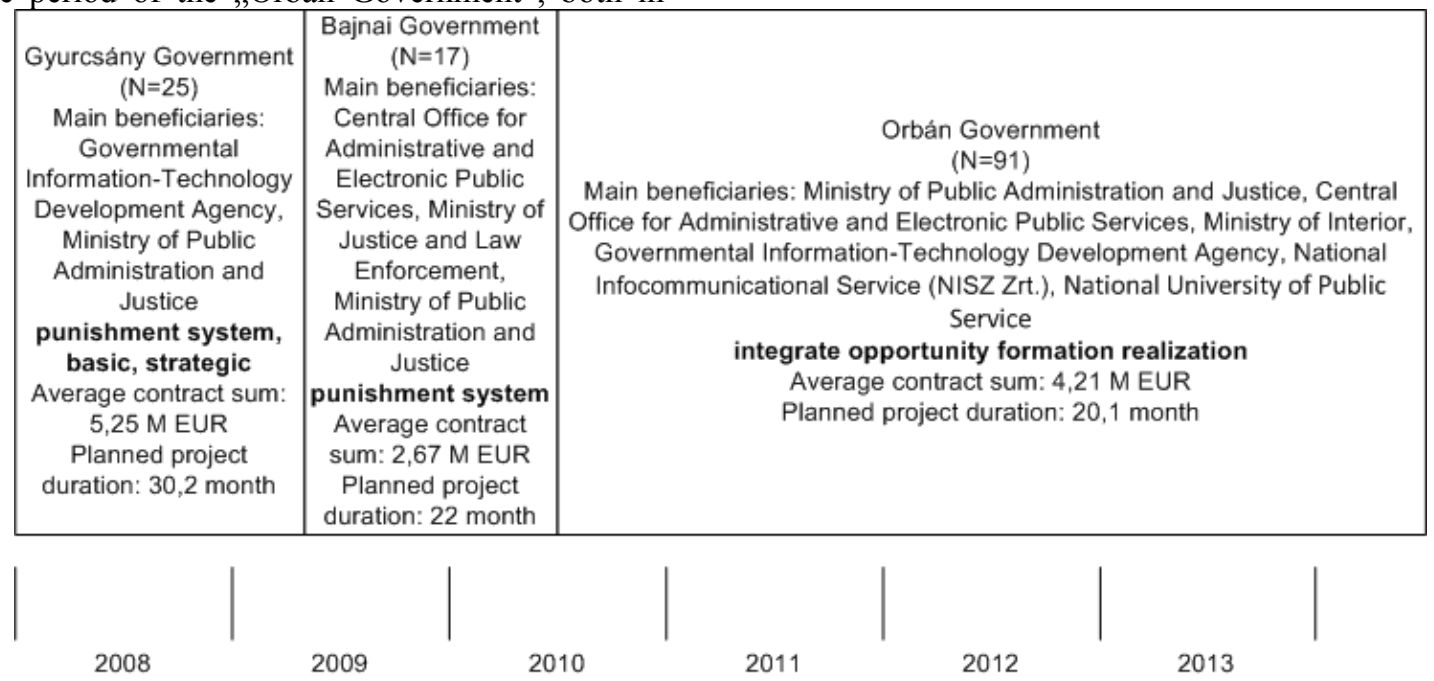

Fig. 10. Governments influence on EPAOP and SROP projects (only the significant differences displayed, $\alpha<10 \%$ )

\section{CONCLUSION}

The main objective of our research has been to explore the financial and timing characteristics of public ICT spending, and analyse the implicit and explicit objective system of eGovernment projects in Hungary. Based on text analysis of two main operative programmes - Electronic Public Administration Operative Programme and State Reform Operative Programme (EPAOP and SROP) - we found that keyword statistics are generally consistent with main policy level objectives of the Operative Programmes, however there are some fields which are not emphasized among project goals, such as: the role of participation and social partners, local government, and improvement of user skills through public information campaigns.

The relationship between SROP and EPAOP goal structures - the human and technology focused aspects of eGovernment development - were also compared, and the results of cluster analysis demonstrate the consistency of goal structures of several EPAOP and SROP projects.

One of our most interesting findings was in terms of timing: contracting in EPAOP and SROP happened in two separate waves with a relatively passive period in 2010-2011, not independent of governmental cycles. A significant amount of founds was committed relatively late in the planning period, in the second half of 2012 and during the year 2013, indicating that governmental changes resulted in reconfiguration of the goal system.

We are aware of some limitations of our data collection and methodology regarding ICT-related public projects - these limitations stem from the following sources:

- We concentrate only the IT projects in the public sector financed from Structural Funds, but in Hungary and in other EU countries there can be IT projects financed from other sources as well.
- Although Structural Funds are the most harmonized public investment schemes in the EU, more attention to harmonized data collection and analysis could provide extremely valuable input for economic impact assessment of ICT projects. At present, comparative data is still limited, member states do not collect and offer data and information on public IT projects in the same or similar structure.

- Our research has focused on the policy objectives and project deliverables, not on execution and actual results - so this is only the first step toward mapping the egovernment value creation process.

These limitations offer directions for further research about public ICT project effectiveness: research should continue data collection concerning the execution phase, examining the consistency of objectives with the actual deliverables and outcomes. Another extension of our "goal hierarchy" approach might be the wider European comparison of such policyproject consistency analysis research endeavours to explore ecohesion at a multinational scale.

\section{REFERENCES}

[1] European Commission, Delivering on the European Advantage? "How European Governments can and should Benefit from innovative public services" e-Government Benchmark, DG Communications, Networks, Content and Technology, 2014

[2] United Nations E-Government Survey 2014, Department of Economic and Social Affairs, United Nations, 2014

[3] European Commission. Scoreboard 2014 - Developments in eGovernment in the EU 2014. 2014. https://ec.europa.eu/digitalagenda/en/news/scoreboard-2014-developments-egovernment-eu-2014. Retrieved: 26/11/2014

[4] Sasvari, P. The macroeconomic effect of the information and communication technology in Hungary. International Journal of Advanced Computer Science and Applications, 2011.2 (12), 75-81.

[5] Lips, M. E-Government is dead: Long live Public Administration 2.0. Information Polity. 2012. 17 (3-4), 239-250.

[6] Barr, N. The Welfare State as Piggy Bank, Information, Risk, Uncertainty, and the Role of the State, Oxford University Press, 2001. 
[7] Bannister, F., Connolly, R. Forward to the past: Lessons for the future of e-government from the story so far. Information Polity. 2012. 17 (3-4), 211-226.

[8] Kanaan, R., Kanaan, G. The Failure of E-government in Jordan to Fulfill Potential. International Journal of Advanced Computer Science \& Applications. 2013. 4(12). 157-161.

[9] Sensuse, D. I., Ramadhan, A. The Relationships of Soft Systems Methodology (SSM), Business Process Modeling and e-Government. International Journal of Advanced Computer Science and Applications, 2012.3(1).
[10] Brynjolfsson, E., Hitt, L. M., Yang, S. Intangible assets: Computers and organizational capital. Brookings Papers on Economic Activity. 2002/1. 137-198.

[11] European Commission. Report on the Implementation of the Electronic Public Administration Operational Programme in 2012. Annual Implementation Report 2012. Approved by the EPAOP Monitoring Committee 11 June 2013. Submitted to the European Commission by 30 June 2013. Website of DG Region: ec.europa.eu/regional_policy/country/prordn/details_new.cfm?gv_PAY $=H U \& g v \_r e g=A L L \& g v \_P G M=1181 \& L A N=7 \& g v \_p e r=2 \& g v \_d e f L=7$ Retrieved: 10/11/2013 